University of Nebraska - Lincoln

DigitalCommons@University of Nebraska - Lincoln

Agronomy \& Horticulture - Faculty Publications

Agronomy and Horticulture Department

2010

\title{
Efficient Methods of Estimating Switchgrass Biomass Supplies
}

Marty R. Schmer

USDA-ARS, University of Nebraska-Lincoln, marty.schmer@ars.usda.gov

Robert B. Mitchell

USDA-ARS, University of Nebraska-Lincoln, rob.mitchell@ars.usda.gov

Kenneth P. Vogel

USDA-ARS, University of Nebraska-Lincoln, kvogel1@unl.edu

Walter H. Schacht

USDA-ARS, University of Nebraska-Lincoln, wschacht1@unl.edu

David B. Marx

University of Nebraska-Lincoln, david.marx@unl.edu

Follow this and additional works at: https://digitalcommons.unl.edu/agronomyfacpub

Part of the Plant Sciences Commons

Schmer, Marty R.; Mitchell, Robert B.; Vogel, Kenneth P.; Schacht, Walter H.; and Marx, David B., "Efficient Methods of Estimating Switchgrass Biomass Supplies" (2010). Agronomy \& Horticulture -- Faculty Publications. 550.

https://digitalcommons.unl.edu/agronomyfacpub/550

This Article is brought to you for free and open access by the Agronomy and Horticulture Department at DigitalCommons@University of Nebraska - Lincoln. It has been accepted for inclusion in Agronomy \& Horticulture -Faculty Publications by an authorized administrator of DigitalCommons@University of Nebraska - Lincoln. 


\title{
Efficient Methods of Estimating Switchgrass Biomass Supplies
}

\author{
Marty R. Schmer • Robert B. Mitchell • \\ Kenneth P. Vogel • Walter H. Schacht • David B. Marx
}

Published online: 26 January 2010

(C) US Government 2010

\begin{abstract}
Switchgrass (Panicum virgatum L.) is being developed as a biofuel feedstock for the United States. Efficient and accurate methods to estimate switchgrass biomass feedstock supply within a production area will be required by biorefineries. Our main objective was to determine the effectiveness of indirect methods for estimating biomass yields and composition of switchgrass fields. Indirect measurements were conducted in eastern Nebraska from 2003 to 2007 in which switchgrass biomass yields were manipulated using three nitrogen rates $\left(0 \mathrm{~kg} \mathrm{~N} \mathrm{ha}^{-1}\right.$, $60 \mathrm{~kg} \mathrm{~N} \mathrm{ha}^{-1}$, and $120 \mathrm{~kg} \mathrm{~N} \mathrm{ha}^{-1}$ ) and two harvest periods (August and post-killing frost). A modified Robel pole was used to determine visual obstruction, elongated leaf height, and canopy height measurements. Prediction models from the study showed that elongated leaf height, visual obstruction, and canopy height measurements accounted for $>91 \%,>90 \%$, and $>82 \%$ of the variation in switchgrass
\end{abstract}

M. R. Schmer $(\square)$

USDA-ARS, Northern Great Plains Research Laboratory,

P.O. Box 459, Mandan, ND 58554, USA

e-mail: marty.schmer@ars.usda.gov

R. B. Mitchell • K. P. Vogel

USDA-ARS, Grain, Forage, and Bioenergy Research Unit, University of Nebraska,

P.O. Box 830737 , Lincoln, NE 68583, USA

W. H. Schacht

Department of Agronomy and Horticulture,

University of Nebraska-Lincoln,

377L Plant Science Hall,

Lincoln, NE 68583-0915, USA

D. B. Marx

Department of Statistics, University of Nebraska-Lincoln, 340 Hardin Hall North,

Lincoln, NE 68583-0963, USA biomass, respectively. Regression slopes were similar by cultivar ("Cave-in-Rock" and "Trailblazer"), harvest period, and across years indicating that a single model is applicable for determining biomass feedstock supply within a region, assuming similar harvesting methods. Sample numbers required to receive the same level of precision were as follows: elongated leaf height $<$ canopy height $<$ visual obstruction. Twenty to 30 elongated leaf height measurements in a field could predict switchgrass biomass yield within $10 \%$ of the mean with $95 \%$ confidence. Visual obstruction is recommended on switchgrass fields with low to variable stand densities while elongated leaf height measurements would be recommended on switchgrass fields with high, uniform stand densities. Incorporating an ocular device with a Robel pole provided reasonable frequency estimates of switchgrass, broadleaf weeds, and grassy weeds at the field scale.

Keywords Bioenergy · Indirect measurement . Sward height $\cdot$ Switchgrass $\cdot$ Visual obstruction

\author{
Abbreviations \\ CRP Conservation reserve program \\ GAT Grassland assessment tool
}

\section{Introduction}

Switchgrass is being developed as a bioenergy crop for the Great Plains, U.S.A. An estimated three to 21 million ha of existing agricultural land in the U.S. is projected to be rotated into a perennial bioenergy cropping system based on theoretical market prices [10]. Agricultural land for perennial grass bioenergy systems likely will come from 
marginal land currently in crop production and land currently enrolled in the conservation reserve program (CRP) [4, 10, 28].

Projected cellulosic refineries will require substantial amounts of biomass on a year-round basis. Biomass refineries are expected to have four to five times higher capital costs than similar sized grain ethanol plants based on first generation biomass refining technology [29]. A reliable feedstock supply will be essential in maintaining stable operational costs. Efficient and accurate methods to estimate switchgrass biomass feedstock supply prior to harvest will be needed to efficiently plan a biorefinery's operation. Methods to estimate harvestable biomass may include or be a combination of remote-sensing measurements, crop models, and ground-based measurements.

Destructive sampling (clip measurements) is the most accurate ground-based form of measuring vegetation biomass but is time and labor-consuming. Nondestructive methods have been used to rapidly measure biomass with less labor [1]. Visual obstruction has accurately measured standing crop in tallgrass vegetation $[16,23]$ by integrating plant height and density. Sward height measurements have been used to estimate standing crop in pastures $[5,6,11]$.

Traditionally, visual obstruction and sward height measurements have been used to estimate total above ground biomass for wildlife or grassland management [7]. Regression models between clipped areas and non-destructive sampling techniques are used to validate the accuracy of each component. Switchgrass grown for bioenergy will be harvested mechanically and estimating total aboveground biomass will be less important than estimating harvestable biomass. Visual obstruction measurements or sward height measurements have not been evaluated for machine harvested biomass yields.

A tool that can effectively measure yield and have the ability to quantify species composition at different parts of the growing season would be helpful to producers and researchers to prescribe proper management goals. A modified visual obstruction pole has been used to estimate species composition and standing crop in rangeland [12]. The applicability of this technique to switchgrass managed for biomass energy has not been evaluated.

The objective of this study was to compare the effectiveness of visual obstruction and two sward height measurements for estimating harvestable switchgrass yield. In addition, we evaluated the use of a modified visual obstruction pole for estimating switchgrass and weedy plant species stands within fields. These sampling methods were evaluated for their utility as rapid yield assessment tools for perennial biomass energy crops such as switchgrass.

\section{Materials and Methods}

Switchgrass Carbon Sequestration Study

The research was conducted using a long-term switchgrass C sequestration experiment [22] at the University of Nebraska Agricultural Research and Development Center (ARDC) near Mead, NE, and a regional field-scale switchgrass trial that evaluated production economics [15], soil C storage [,8], and net energy [18]. Soil on the ARDC study site is classified as an Aksarben silty clay loam (fine, smectitic, mesic Typic Argiudolls). The switchgrass $\mathrm{C}$ sequestration study has cultivar, $\mathrm{N}$ rate, and harvest treatments to induce different production levels to determine the affect of treatments and biomass yield on $\mathrm{C}$ sequestration. The main treatment plot was switchgrass cultivar, split-plot was nitrogen $(\mathrm{N})$ treatment, and splitsplit plot was harvest date. Switchgrass was seeded in 1998 using cultivars "Cave-in-Rock" and "Trailblazer" with three $\mathrm{N}$ rates $\left(0 \mathrm{~kg} \mathrm{~N} \mathrm{ha}{ }^{-1}, 60 \mathrm{~kg} \mathrm{~N} \mathrm{ha}^{-1}\right.$, and $\left.120 \mathrm{~kg} \mathrm{~N} \mathrm{ha}^{-1}\right)$ beginning in 2000, with three replicates per treatment combination. Nitrogen was broadcasted in spring as $\mathrm{NH}_{4} \mathrm{NO}_{3}$. Split-plot dimensions are $18 \times 30 \mathrm{~m}$ and splitsplit plot dimensions are $9 \times 30 \mathrm{~m}$. Switchgrass was managed as a bioenergy crop with a single harvest per year. Harvesting was done by flail chopping a $0.9 \mathrm{~m}$ swath the length of the plots at the early reproductive (R2) stage of development [14] or after a killing frost using a selfpropelled harvester with weigh box (Carter Manufacturing Co., Brookston, $\mathrm{IN}^{1}$ ). Plots were cut at a $10-\mathrm{cm}$ height, and all herbage was weighed immediately following harvest. Subsamples were taken from each plot at time of harvest, weighed in the field, and oven-dried at $55^{\circ} \mathrm{C}$ to a constant weight to determine percentage dry matter.

Visual obstructions and sward height measurement were made in 2003, 2005, 2006, and 2007. Visual obstruction was measured on the day of mechanical harvest using a modified Robel pole [16] having a 2-m tall graduated pole marked at 5 -cm wide increments (Fig. 1). The sight pole and graduated pole is attached with a 4-m length rope. Visual obstruction was conducted with an observer standing 4-m away from the graduated pole using the sight pole to read the graduated pole at a height of 1-m from the ground. A visual obstruction reading was recorded by identifying the lowest visible increment on the graduated pole. Increments that were partially obstructed by vegetation were considered visible. Sward height measurements were taken using the graduated pole. Sward height was measured on

\footnotetext{
${ }^{1}$ Trade and company names or commercial products is solely for the purpose of providing specific information and does not imply recommendation of endorsement by the U.S. Department of Agriculture.
} 


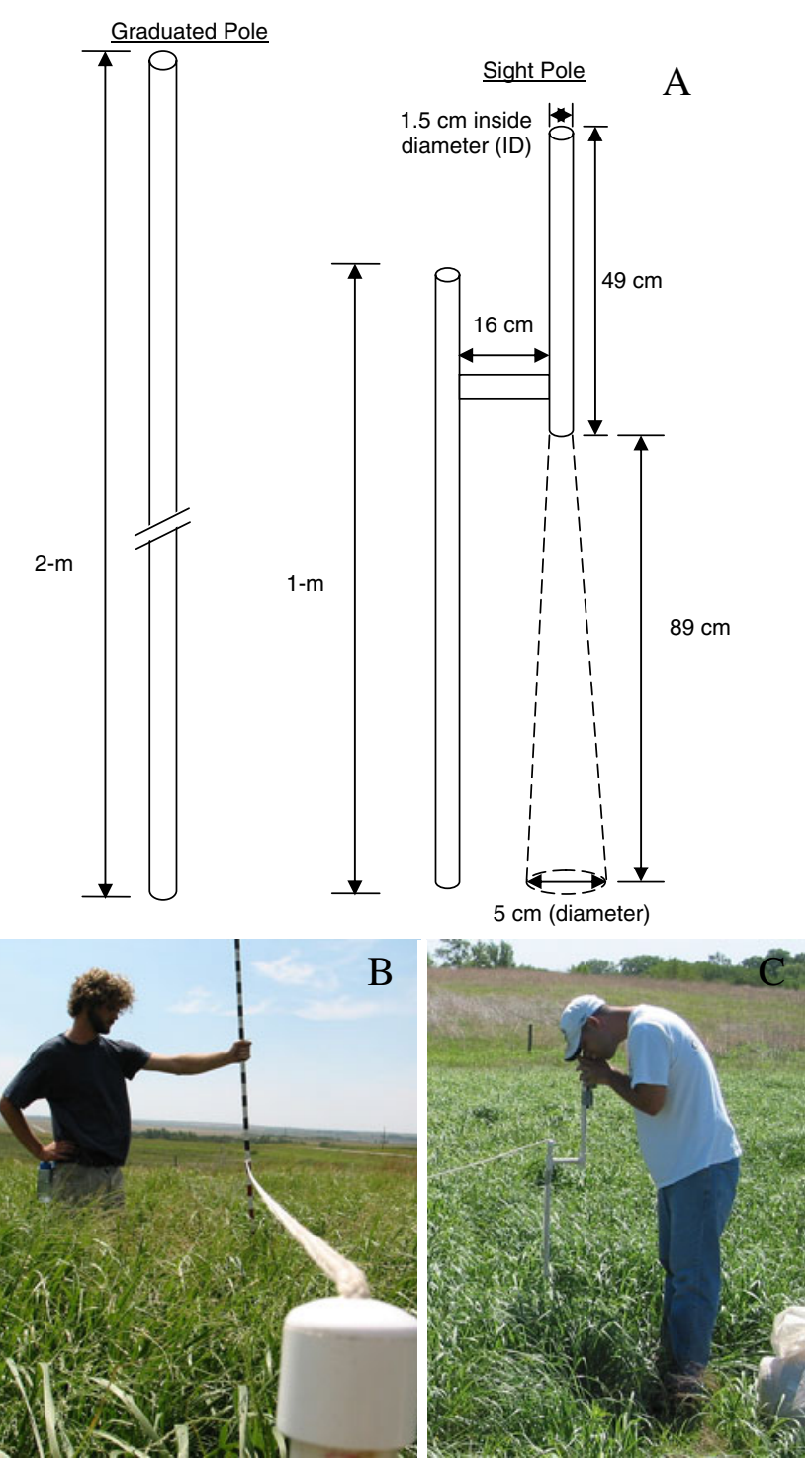

Fig. 1 Diagram of the grassland assessment tool (GAT) with an attached ocular piece and a $2-\mathrm{m}$ graduated pole marked with $5-\mathrm{cm}$ vertical increments (a). The sight pole and graduated pole is attached with a 4-m length rope (b). Visual obstruction [16] was conducted with an observer standing $4 \mathrm{~m}$ away from the graduated pole using the sight pole to read the graduated pole at a height of $1 \mathrm{~m}$ from the ground (b). Canopy height and elongated leaf height measurements were taken using the graduated pole (b; background pole). Frequency of occurrence is made by the observer looking directly down from the attached ocular piece which allows for a $5 \mathrm{~cm}$ diameter viewing circle at the soil surface $(\mathbf{c})$

the 2-m graduated pole using the elongated vertical height of the uppermost leaf or canopy height which is the height of the flag leaf taken at the flag leaf collar. Five visual obstruction and sward height measurements were taken per split-split plot along an adjacent transect to the harvested area to avoid potential lodging. Regression analysis was performed on the average visual obstruction and sward height plot measurements with harvested dry matter yields.
Interaction effects $(P \leq 0.05)$ between cultivar, harvest date, and year were analyzed using generalized linear models to determine equality of slopes for each indirect measurement evaluated.

The number of samples required to obtain switchgrass yield estimates within $10 \%$ and $20 \%$ of the mean, respectively, at a $95 \%$ confidence level for each indirect method were determined using the formula:

$n=\frac{t^{2} s^{2}}{d^{2}}$

where $n$ is the sample number, $t$ is the tabulated $t$ value for a $95 \%$ confidence, $s^{2}$ is the variance of each individual indirect visual estimate method sample, and $d$ is one half the indirect measurement mean $[20,21]$. Formula (a) has been used to evaluate quadrat efficiency in estimating rangeland biomass [2]. Sample number requirements were calculated for each $\mathrm{N}$ treatment by harvest treatment and across all $\mathrm{N}$ treatments by harvest treatment for the switchgrass $\mathrm{C}$ study.

\section{On-farm Switchgrass Study}

An on-farm study was conducted on four switchgrass fields in Nebraska, four in South Dakota, and two in North Dakota [17]. Field size ranged from 3 to 9.5 ha with an average of 6.7 ha. Fields were established in 2000 and 2001. The study ended in 2004 for the Nebraska sites and 2005 for the South Dakota and North Dakota sites. Fields were chosen based on characteristics of the region and qualification for CRP. Soil type, cropping history, cultivars, and agronomic practices have been previously described for the on-farm switchgrass study $[8,15,17]$.

For the on-farm study, a Robel pole was modified (Fig. 1) to include a sight piece [hereafter designated as grassland assessment tool (GAT)] to estimate the frequency of switchgrass, grassy weeds, and broadleaf weeds [12]. The vertical ocular piece was attached $16 \mathrm{~cm}$ from the sight pole and measured $89 \mathrm{~cm}$ from the soil surface to the bottom of the ocular piece (Fig. 1). The ocular piece measures $49 \mathrm{~cm}$ in length and has a $1.5 \mathrm{~cm}$ inside diameter which allows the user to see a $5-\mathrm{cm}$ diameter circle at the soil surface [12]. Grassland assessment tool can be used independently to quantify frequency of occurrence or in conjunction with the Robel pole to measure both frequency of occurrence and visual obstruction.

A total of 25 sample sites were measured per field in 2003, 2004, and 2005 using GAT and a $0.75 \times 0.75-\mathrm{m}$ frequency grid containing 25 cells [25] in June. Sites were stratified based on cultivar and/or topographic characteristics, then quadrats were randomly located within strata. A 12-channel global positioning system receiver (Lowrance 
Globalmap 1001; Catoosa, OK) was used to geo-reference each quadrat site to allow for repeated measurements within and across years. At each quadrat site, presence or absence of plants in each of the 25-grid cells was recorded and flipped end-to-end until a total of 100 cells was recorded. The percentage of switchgrass, grassy weed, and broadleaf weed tillers $(100$ cells) were recorded for each quadrat site. Four measurements, one in each cardinal direction were taken with GAT where a frequency grid was used to estimate switchgrass, broadleaf weeds, and grassy weeds per quadrat site to give 100 observations per field. The presence of any switchgrass, grassy weed, or broadleaf weed plant structure that could be seen through the GAT ocular piece was recorded. Regression analysis was performed using mean stand frequency grid and mean GAT measurements for each location by year combination. The same sites within fields were re-sampled in August to measure visual obstruction and sward height using a modified Robel pole mentioned for the switchgrass $\mathrm{C}$ sequestration study. Visual obstruction and elongated leaf height measurements were taken on nine field locations in 2003, ten field locations in 2004, and six field locations in 2005. Canopy height measurements were taken on ten field locations in 2004 and six field locations in 2005. Sample number requirements for the on-farm study at a $95 \%$ confidence level using equation (a) were calculated across locations and years.

\section{Results}

Biomass yields in the switchgrass $\mathrm{C}$ sequestration study ranged from 0.7 to $16.5 \mathrm{Mg} \mathrm{ha}^{-1}$ caused by $\mathrm{N}$ treatments, and hence, the field plots were suitable for assessing the utility of using indirect measurements for a broad range of switchgrass yields. Switchgrass stand frequency was high $(>90 \%)$ in all plots and across years using a frequency grid [25]. Plots at time of harvest were essentially switchgrass monocultures with greatest amounts of non-planted species occurring in the $0 \mathrm{~kg} \mathrm{~N} \mathrm{ha}^{-1}$ treatment plots.

There were no significant $(P=0.05)$ slope differences between cultivar, harvest treatment, or years for visual obstruction, elongated leaf height, and canopy height within the switchgrass $\mathrm{C}$ sequestration study. Therefore, cultivar, harvest treatment, and years were pooled together for visual obstruction, elongated leaf height, and canopy height to determine significant linear or polynomial equations. A significant quadratic relationship was found for visual obstruction and elongated leaf height whereas a cubic relationship was found to be significant for canopy height (Table 1). Visual obstruction and elongated leaf height using either the linear or quadratic models accounted for $>90 \%$ of the variation in standing crop, whereas canopy height accounted for $>82 \%$ of the variation based on linear and polynomial models (Table 1). Sward measurements using elongated leaf height values or visual obstruction (Fig. 2) had higher coefficient of determination and lower mean square errors than canopy height.

Sample numbers required to be within $10 \%$ and $20 \%$ of the mean for each method are presented in Table 2 for the switchgrass $\mathrm{C}$ sequestration study. The number of samples required for a given level of precision was smallest for the elongated leaf height method, followed by the canopy height method and the visual obstruction method (Table 2). Sample number requirements to be within $10 \%$ of the mean at a $95 \%$ confidence level ranged from 13 to 110 for the 60 and $120 \mathrm{~kg} \mathrm{~N} \mathrm{ha}^{-1}$ treatment plots (Table 2). Pooling $\mathrm{N}$ treatments across years from the switchgrass $\mathrm{C}$ sequestration study gives an estimate on the number of samples required for a given level of precision for fields with large biomass yield heterogeneity. Elongated leaf height had the lowest sample number requirement followed by canopy height and visual obstruction when indirect measurements were pooled across $\mathrm{N}$ treatments (Table 2). A similar result was found from the on-farm study where elongated leaf height had lower sample number requirements than either

Table 1 Linear and polynomial regression models, mean square errors (MSE), and coefficient of determination $\left(r^{2}\right)$ for switchgrass standing crop, visual obstruction (VO), elongated leaf height $(\mathrm{ELH})$, and canopy height $(\mathrm{CH})$ in a multi-year, variable nitrogen treatment study in Eastern Nebraska

\begin{tabular}{llcc}
\hline Parameter & Regression models & MSE & $r^{2}$ values \\
\hline VO (linear) & $-0.954+0.0811(\mathrm{VO})$ & 1.42 & 0.90 \\
VO (quad) & $0.453+0.039(\mathrm{VO})+0.0024(\mathrm{VO})^{2}$ & 1.28 & 0.91 \\
ELH (linear) & $-6.781+0.111(\mathrm{ELH})$ & 1.26 & 0.91 \\
ELH (quad) & $-1.462+0.0126(\mathrm{ELH})+0.0004(\mathrm{ELH})^{2}$ & 2.64 & 0.93 \\
CH (linear) & $-3.633+0.114(\mathrm{CH})$ & 2.51 & 0.82 \\
CH (quad) & $-1.191+0.050(\mathrm{CH})+0.00037(\mathrm{CH})^{2}$ & 2.41 \\
CH (cubic) & $2.937-0.129(\mathrm{CH})+0.0026(\mathrm{CH})^{2}-0.000009(\mathrm{CH})^{3}$ & 0.83 \\
\hline
\end{tabular}

The dependent variable was switchgrass standing crop (megagrams per hectare) and independent variables were VO, ELH, and CH (centimeters). All regression models shown were significant at $P \leq 0.01$ 

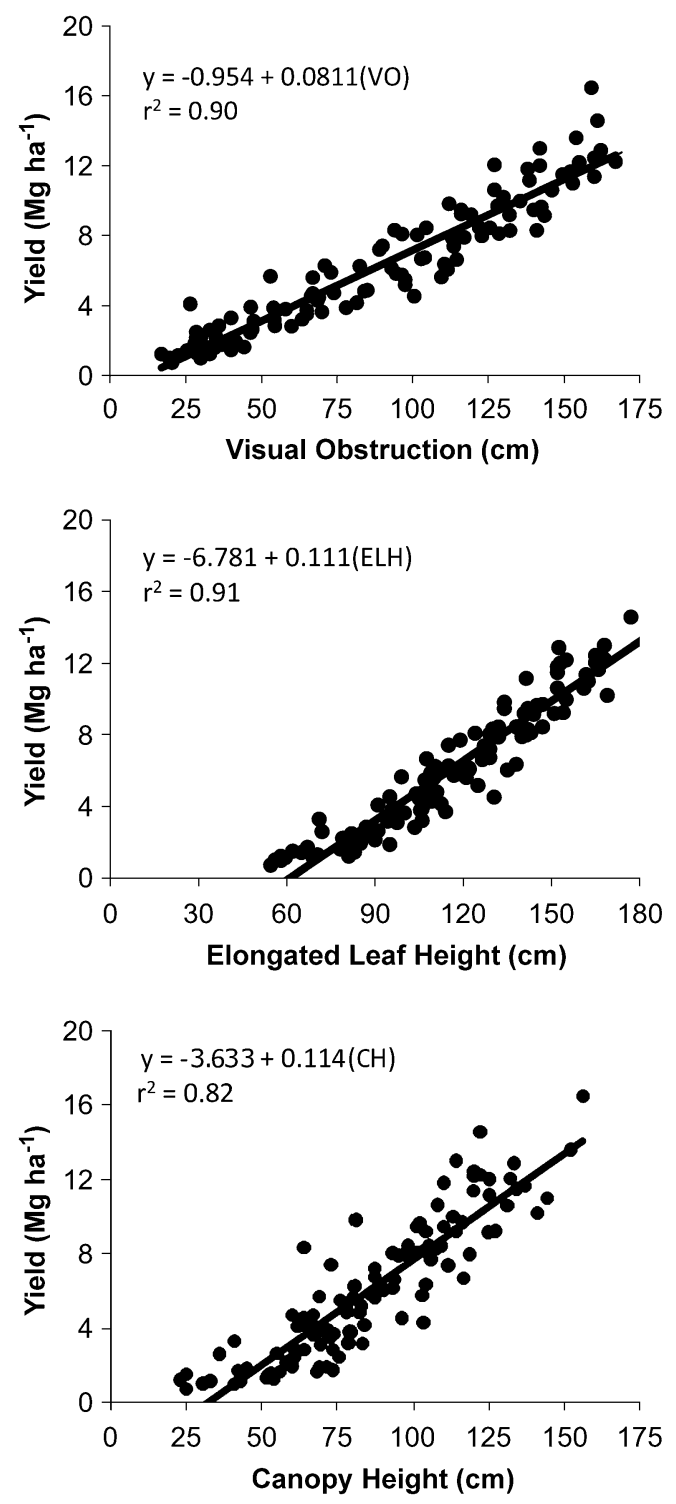

Fig. 2 Relationship between switchgrass standing crop (mega grams per hectare), visual obstruction, elongated leaf height, and canopy height (centimeters) in Eastern Nebraska. Measurements were taken from multiple years $(2003,2005,2006$, and 2007) from two sampling dates (August and post-frost harvest) on two switchgrass cultivars (Cave-inRock and Trailblazer) under different nitrogen treatments $\left(0 \mathrm{~kg} \mathrm{~N} \mathrm{ha}^{-1}\right.$, $60 \mathrm{~kg} \mathrm{~N} \mathrm{ha}^{-1}$, and $120 \mathrm{~kg} \mathrm{~N} \mathrm{ha}^{-1}$ ). Linear models are presented while significant polynomial regression models are given in Table 1

visual obstruction or canopy height measurements (Table 3). Sample number requirements for the switchgrass $\mathrm{C}$ sequestration study pooled across $\mathrm{N}$ treatments and years were greater than regional field-scale switchgrass trials averaged across years (Tables 2 and 3). The mean height variances from the on-farm trials averaged across years (Table 3) were similar to those of the within $\mathrm{N}$ treatment variances from the $\mathrm{C}$ sequestration study (Table 2), suggesting that height heterogeneity at the field scale is not as large as when mean height measurements were taken across $\mathrm{N}$ treatments.
From the on-farm switchgrass fields, GAT measurements accounted for $89 \%$ and $91 \%$ of the variation for grassy weeds and broadleaf weeds, respectively, as compared with stand frequency grid estimates (Fig. 3). However, GAT overestimated switchgrass frequency when compared with the frequency grid (Fig. 3). The lower coefficient of determination for switchgrass result could have resulted from a narrower range of frequencies than observed for either grassy weeds or broadleaf weeds. The frequency grid measures the presence/absence of tillers in a given cell, whereas GAT measures the presence/absence of any plant material that can be seen through the ocular device. Switchgrass at all locations was more mature than broadleaf weeds and grassy weeds and had considerable leaf material at time of observations, especially at the southern Nebraska locations which could account for GAT having higher mean values than the frequency grid.

\section{Discussion}

Indirect measurement methods can be used to predict switchgrass yield harvested mechanically. Polynomial regression models were found to be significant for elongated leaf height, visual obstruction, and canopy height, but only accounted for $1 \%$ to $2 \%$ more of the variation than linear regression models (Table 1). Visual obstruction and sward height measurements have been evaluated traditionally using linear models. Polynomial models were better predictors than linear models when low-yielding plots $\left(<2 \mathrm{Mg} \mathrm{ha}^{-2}\right)$ were included (Fig. 2). Plots with low yields were from the $0 \mathrm{~kg} \mathrm{~N} \mathrm{ha}^{-1}$ treatments. Nitrogen fertilizer is required to produce adequate yields for switchgrass to be economically competitive with other cropping systems in the Great Plains. A linear model is sufficient in estimating yield under expected switchgrass agronomic practices for bioenergy.

Elongated leaf height was found to be as effective in estimating switchgrass biomass as the visual obstruction method. Previous research reported that visual obstruction measurements tend to be better predictors of standing crop than sward height measurements within pasture environments $[5,6]$. Plant heterogeneity is common within most native and pasture systems which would favor visual obstruction measurements due to varying sward densities. All plots in this study had high, uniform stand densities. Sward height measurements require fewer personnel and allow more samples to be collected than visual obstruction in a given amount of time. Elongated leaf height and canopy height measurements required fewer samples for a given level of precision than visual obstruction measurements (Table 2). Elongated leaf height was superior in terms of a large 
Table 2 Mean height (centimeters), variance $\left(s^{2}\right)$, and variance sample number required to obtain indirect standing crop measurements to be within $10 \%$ and $20 \%$ of the mean with $95 \%$ confidence

Sample number requirements were evaluated by nitrogen $(\mathrm{N})$ treatments, harvest periods in August or post-frost harvest, and across $\mathrm{N}$ treatments in a longterm switchgrass carbon sequestration study

\begin{tabular}{|c|c|c|c|c|c|}
\hline \multirow[t]{2}{*}{ Harvest period } & \multirow[t]{2}{*}{$\mathrm{N}, \mathrm{kg} \mathrm{ha}^{-1}$} & \multirow[t]{2}{*}{ Mean height, $\mathrm{cm}$} & \multirow[t]{2}{*}{$s^{2}$ values, $\mathrm{cm}^{2}$} & \multicolumn{2}{|c|}{ Sample no. } \\
\hline & & & & $10 \%$ & $20 \%$ \\
\hline & \multicolumn{5}{|c|}{ Visual obstruction } \\
\hline August & 0 & 38 & 203 & 158 & 40 \\
\hline August & 60 & 87 & 747 & 110 & 28 \\
\hline August & 120 & 122 & 656 & 49 & 12 \\
\hline Across $\mathrm{N}$ treatments & & 82 & 1,747 & 284 & 83 \\
\hline Post-frost harvest & 0 & 42 & 206 & 130 & 33 \\
\hline Post-frost harvest & 60 & 113 & 565 & 49 & 13 \\
\hline Post-frost harvest & 120 & 145 & 388 & 21 & 6 \\
\hline \multirow[t]{2}{*}{ Across $\mathrm{N}$ treatments } & & 99 & 2,388 & 269 & 68 \\
\hline & \multicolumn{5}{|c|}{ Elongated leaf height } \\
\hline August & 0 & 79 & 273 & 49 & 13 \\
\hline August & 60 & 113 & 362 & 32 & 8 \\
\hline August & 120 & 138 & 333 & 20 & 5 \\
\hline Across $\mathrm{N}$ treatments & & 110 & 910 & 83 & 21 \\
\hline Post-frost harvest & 0 & 84 & 286 & 43 & 11 \\
\hline Post-frost harvest & 60 & 138 & 353 & 21 & 6 \\
\hline Post-frost harvest & 120 & 163 & 309 & 13 & 4 \\
\hline \multirow[t]{2}{*}{ Across $\mathrm{N}$ treatments } & & 129 & 1,381 & 92 & 23 \\
\hline & \multicolumn{5}{|c|}{ Canopy height } \\
\hline August & 0 & 57 & 472 & 163 & 41 \\
\hline August & 60 & 86 & 481 & 71 & 18 \\
\hline August & 120 & 104 & 397 & 41 & 11 \\
\hline Across $\mathrm{N}$ treatments & & 82 & 830 & 135 & 34 \\
\hline Post-frost harvest & 0 & 64 & 254 & 69 & 17 \\
\hline Post-frost harvest & 60 & 102 & 424 & 45 & 12 \\
\hline Post-frost harvest & 120 & 126 & 434 & 31 & 8 \\
\hline Across $\mathrm{N}$ treatments & & 96 & 1,125 & 135 & 35 \\
\hline
\end{tabular}

coefficient of determination, low mean square error, and sample number requirements to both canopy height measurements and visual obstruction. Based on the results from both trials, 20 to 30 elongated leaf height measurements in fields fertilized with adequate levels of $\mathrm{N}$ could predict switchgrass biomass yield within $10 \%$ of the mean with $95 \%$ confidence.

Visual obstruction had the largest variances of any of the assessment techniques for any $\mathrm{N}$ treatment (Table 2). This was partially caused by the sight pole located below the plant canopy when switchgrass was $>1 \mathrm{~m}$. The observer traditionally is above the plant canopy and looks down from the sight pole to the graduated pole to estimate standing crop when using the Robel pole. With plant canopies $>1 \mathrm{~m}$, the observer is looking up and through the plant canopy at the graduated pole to sight unobstructed markings. Canopy obstruction close to and above the sight pole can lead to larger variations in yield estimates than using either canopy height or elongated leaf height measurements from a graduated pole. Altering the sight pole to have a height above the traditional $1 \mathrm{~m}$ would likely lower the overall variation and reduce overall sample numbers required for a given level of precision when estimating switchgrass yield.

Table 3 Mean height (centimeters), variance $\left(s^{2}\right)$, and variance sample number required to obtain visual obstruction (VO), elongated leaf height (ELH), and canopy height $(\mathrm{CH})$ measurements to be within $10 \%$ and $20 \%$ of the mean with $95 \%$ confidence from a regional, field-scale switchgrass study

\begin{tabular}{lcccr}
\hline & Mean height, $\mathrm{cm}$ & $s^{2}$ values & \multicolumn{2}{l}{ Sample no. } \\
\cline { 4 - 5 } & & & $10 \%$ & $20 \%$ \\
\cline { 3 - 5 } & & & \multicolumn{2}{c}{$\#$} \\
\hline VO & 98 & 564 & 64 & 16 \\
ELH & 132 & 420 & 26 & 7 \\
CH & 83 & 401 & 64 & 16 \\
\hline
\end{tabular}

Sample number requirements were evaluated across years (2003 to 2005) and fields (ten) with varying soil types, fertilizer requirements, and weather conditions 

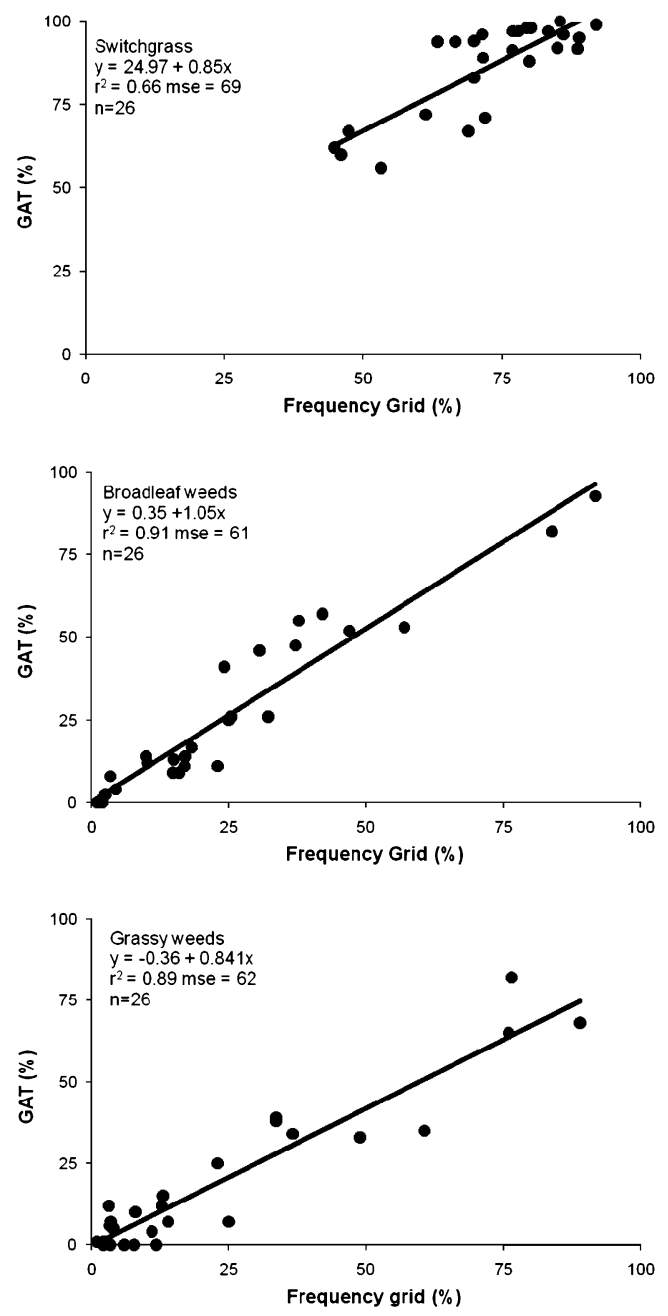

Fig. 3 Relationship between the grassland assessment tool (GAT) and a $0.75 \times 0.75-\mathrm{m}^{2}$ frequency grid in estimating switchgrass and weed stands on ten switchgrass fields in North Dakota, South Dakota, and Nebraska

Visual obstruction measurements would be a better predictor of switchgrass fields with non-uniform or low stand densities since visual obstruction integrates plant height and plant density. Visual obstruction measurements have been shown to be less precise at measuring standing crop when using individual samples than models calibrated to yield trial data [5, 7, 23, 27]. Field-scale data on switchgrass biomass yield variation is limited [19, 24], but height variation from the on-farm switchgrass study suggest that sampling requirements to estimate switchgrass biomass yield is modest (Table 3). Mean height variation data presented was averaged across years. Variation within years will be less than is presented here because temporal variation caused by weather effects on switchgrass yield is significant at the field scale [19]. The sample number requirements shown (Tables 2 and 3 ) are high with respect to estimating yield within years at the field scale.
A disadvantage of all the indirect methods evaluated is that species composition is not estimated, only standing crop. Incorporating an ocular device to a Robel pole (GAT) to estimate species composition has been used to estimate functional group frequency of occurrence in a mixed-grass prairie [12]. The use of a single tool to predict both functional group composition and early growth stage yield would be advantageous in terms of time and labor costs. Grassland assessment tool accounted for less variation in switchgrass than either broadleaf or grassy weeds as compared with the frequency grid. Switchgrass stand frequency means across locations were moderate to high resulting in little frequency variation across location as compared with weed frequency. Switchgrass stand frequency means, using GAT, were in a similar frequency range when compared with the $0.75 \times$ $0.75-\mathrm{m}$ frequency grid. Recommendations for stand frequencies are generally listed within an optimum range. Perennial grass stand frequencies less than $25 \%$ indicate a partial to unsuccessful establishment; stand frequencies between $25 \%$ and $50 \%$ indicate marginal to adequate stands, and stand frequencies above 50\% indicate a fully successful stand [25]. For switchgrass, an establishment stand threshold above $40 \%$ showed no significant differences in post-establishment yields [17]. Grassland assessment tool estimates were within similar ranges when compared with the stand frequency grid, suggesting GAT would be useful in monitoring switchgrass stands.

Switchgrass yield differences by harvest date have been reported for switchgrass in the central and northern Great Plains [3, 26]. Large time differences between sample date and harvest date would impact the accuracy of sward measurements to predict switchgrass yield. Madakadze et al. [9] found a positive, linear relationship between switchgrass dry matter accumulation and canopy height when measured over the growing season. Yield estimates from these prediction models (Table 1) are valid for a $10 \mathrm{~cm}$ cutting height, which is commonly used for switchgrass harvest in the Great Plains [13]. Indirect measurement prediction models will need to be developed based on cutting heights greater than $10 \mathrm{~cm}$ for accurate yield estimates.

Sample number requirements for a given precision level of the mean were relatively few, suggesting that indirect measurements would be a more efficient method to estimate yield than destructive sampling at the field scale. Previous sampling estimates have shown that visual obstruction measurements are six times faster than destructive sampling [23]. Inclusion of an ocular device was an effective way to quantify functional group composition within switchgrass fields. The utility of the ocular device would enable a user to estimate standing crop and species composition at the same time with the same device. Sampling for yield and 
frequency at different time intervals may provide useful information on switchgrass yields across the growing season, weed frequencies and composition, and postherbicide effectiveness on weed populations. Switchgrass crop yield models and remote-sensing estimates could be validated periodically using ground-based indirect measurements. Indirect methods to estimate biomass would be useful as a rapid yield assessment tool for bioenergy producers, biorefinery operators, and government agencies. Further research into increasing the sight pole height above $1-\mathrm{m}$ for visual obstruction measurements is warranted to determine if this would lead to greater accuracy and less variability on switchgrass grown for bioenergy. Indirect measurement models based specifically on switchgrass lowland ecotypes and other perennial grass species will need to be developed. The use of mixed-grass species as a bioenergy feedstock would increase stand and height heterogeneity with visual obstruction measurements being more advantageous over sward height measurements to predict yield. As bioenergy specific cultivars are released with greater yield potential, further model refinement will be required to accurately predict biomass potential.

\section{References}

1. Benkobi L, Uresk DW, Schenbeck GS, King RM (2000) Protocol for monitoring standing crop in grasslands using visual obstruction. J Range Manag 53:627-633

2. Brummer JE, Nichols JT, Engel RK, Eskridge KM (1994) Efficiency of different sizes and shapes for sampling standing crop. J Range Manag 47:84-89

3. Casler MD, Boe AR (2003) Cultivar $\mathrm{x}$ environment interactions in switchgrass. Crop Sci 43:2226-2233

4. Fargione J, Hill J, Tilman D, Polasky S, Hawthorne P (2008) Land clearing and the biofuel carbon debt. Science 319:1235-1238

5. Ganguli AC, Vermeire LT, Mitchell RB, Wallace MC (2000) Comparision of four nondestructive techniques for estimating standing crop in shortgrass plains. Agron J 92:1211-1215

6. Harmoney KR, Moore KJ, George R, Brummer EC, Russell JR (1997) Determination of pasture biomass using four indirect methods. Agron J 89:665-672

7. Jackson RD, Paine LK (2006) Revisiting Robel's visual obstruction method for estimation of standing crop in grasslands. Forage and Grazinglands. doi:10.1094/FG-2006-1213-01-RS

8. Liebig MA, Schmer MR, Vogel KP, Mitchell RB (2008) Soil carbon storage of switchgrass grown for bioenergy. Bioenerg Res $1: 215-222$

9. Madakadze IC, Stewart K, Peterson PR, Coulman BE, Smith DL (1999) Switchgrass biomass and chemical composition for biofuel in eastern Canada. Agron J 91:696-701
10. McLaughlin SB, De La Torre Ugarte DG Jr, Garten CT, Lynd LR, Sanderson MA, Tolbert VR et al (2002) High-value renewable energy from prairie grasses. Environ Sci Technol 36:2122-2129

11. Michalk DL, Herbert PK (1977) Assessment of four techniques for estimating yield on dryland pastures. Agron J 69:864-868

12. Mitchell RB, Schmer MR, Vogel KP, Vermeire LT, Derner JD (2005) The grassland assessment tool: a new technique for monitoring grasslands. Society for Range Management Meeting Proceedings Feb. 4-11. Ft. Worth, TX

13. Mitchell RB, Vogel KP, Sarath G (2008) Managing and enhancing switchgrass as a bioenergy feedstock. Biofuels Bioprod Bioref 2:530-539

14. Moore KJ, Moser LE, Vogel KP, Waller SS, Johnson BE, Pedersen JF (1991) Describing and quantifying growth stages of perennial forage grasses. Agron J 83:1073-1077

15. Perrin RK, Vogel KP, Schmer MR, Mitchell RB (2008) Farmscale production cost of switchgrass for biomass. Bioenerg Res 1:91-97

16. Robel RJ, Briggs JN, Dayton AD, Hulbert LC (1970) Relationships between visual obstruction measurements and weight of grassland vegetation. J Range Manag 23:295-297

17. Schmer MR, Vogel KP, Mitchell RB, Moser LE, Eskridge KE, Perrin RK (2006) Establishment stand thresholds for switchgrass grown as a bioenergy crop. Crop Sci 46:157-161

18. Schmer MR, Vogel KP, Mitchell RB, Perrin RK (2008) Net energy of cellulosic ethanol from switchgrass. Proc Natl Acad Sci USA 105:464-469

19. Schmer MR, Mitchell RB, Vogel KP, Schacht WH, Marx DB (2010) Spatial and temporal effects on switchgrass stands and yields in the Great Plains. Bioenerg Res. doi:10.1007/s12155-0099045-y

20. Steel RGD, Torrie JH (1980) Principles and procedures of statistics. McGraw-Hill, New York

21. Stein C (1945) A two-sample test for a linear hypothesis whose power is independent of the variance. Ann Math Stat 16:243-258

22. Varvel GE, Vogel KP, Mitchell RB, Follet RF, Kimble JM (2008) Comparison of corn and switchgrass on marginal soils for bioenergy. Biomass Bioenergy 32:18-21

23. Vermeire LT, Gillen RL (2001) Estimating herbage standing crop with visual obstruction in tallgrass prairie. J Range Manag 54:5760

24. Virgilio ND, Monti A, Venturi G (2007) Spatial variability of switchgrass (Panicum virgatum L.) yield as related to soil parameters in a small field. Field Crops Res 101:232-239

25. Vogel KP, Masters RA (2001) Frequency grid - a simple tool for measuring grassland establishment. J Range Manag 54:653-655

26. Vogel KP, Brejda JJ, Walters DT, Buxton DR (2002) Switchgrass biomass production in the Midwest USA: harvest and nitrogen management. Agron J 94:413-420

27. Volesky JD, Schacht WH, Reece PE (1999) Leaf area, visual obstruction, and standing crop relationships on Sandhills rangeland. J Range Manag 52:494-499

28. Walsh ME, De La Torre Ugarte DG, Shapouri H, Slinsky SP (2003) Bioenergy crop production in the United States. Envir And Resource Econ 24:313-333

29. Wright MM, Brown RC (2007) Comparative economics of biorefineries based on the biochemical and thermochemical platforms. Biofuels Bioprod Bioref 1:49-56 